This item was submitted to Loughborough's Research Repository by the author.

Items in Figshare are protected by copyright, with all rights reserved, unless otherwise indicated.

\title{
Environmental risks, localization and the overseas subsidiary performance of MNEs from an emerging economy
}

\section{PLEASE CITE THE PUBLISHED VERSION}

http://dx.doi.org/10.1016/j.jwb.2015.05.002

\section{PUBLISHER}

(C) Elsevier

VERSION

AM (Accepted Manuscript)

\section{PUBLISHER STATEMENT}

This work is made available according to the conditions of the Creative Commons Attribution-NonCommercialNoDerivatives 4.0 International (CC BY-NC-ND 4.0) licence. Full details of this licence are available at: https://creativecommons.org/licenses/by-nc-nd/4.0/

\section{LICENCE}

CC BY-NC-ND 4.0

\section{REPOSITORY RECORD}

Liu, Xiaohui, Lan Gao, Jiangyong Lu, and Eleni Lioliou. 2015. "Environmental Risks, Localization and the Overseas Subsidiary Performance of Mnes from an Emerging Economy”. Loughborough University. https://hdl.handle.net/2134/18408. 


\title{
Environmental risks, localization and the overseas subsidiary performance of MNEs from an emerging economy
}

\begin{abstract}
Despite the fact that multinational enterprises (MNEs) from emerging economies invest actively in host countries with substantial risks, we have limited understanding of how they manage environmental risks to achieve desirable performance in their overseas subsidiaries. Drawing on resource dependence theory, we argue that different localization strategies serve as a mediating mechanism linking environmental risks and overseas subsidiary performance. Our findings based on a sample of Chinese MNEs show that industry risks significantly reduce the levels of input localization and marketing localization of Chinese MNEs' subsidiaries, and thus negatively affect subsidiary performance. Political risks have an insignificant impact on input localization and marketing localization, but a positive direct impact on Chinese MNEs' overseas subsidiary performance. We also find that state-owned MNEs' localization strategies are more sensitive to industry risks compared with privately owned MNEs.
\end{abstract}

Keywords: Chinese MNEs, environmental risks, localization strategies, subsidiary performance. 


\section{Introduction}

Outward foreign direct investment (FDI) is being increasingly adopted as a key expansion strategy for firms from emerging economies (EEs) (Buckley, Clegg, Cross, Liu, Voss \& Zheng, 2007; Cui \& Jiang, 2012; Lu, Zhou, Bruton \& Li, 2010; Rui \& Yip, 2008; Wang, Hong, Kafouros \& Wright, 2012). This strategy, however, is associated with several difficult challenges because of the heightened international exposure, competition and additional environmental risks present in foreign host countries (Elango, 2009; Lu, Liu, Wright \& Filatotchev, 2014; Jimenes \& Delgado-Garcia, 2012). Environmental risks in host countries, such as political and industry risk, represent uncertainties and potential threats for multinational enterprises (MNEs) (Cuypers \& Martin, 2010; Henisz, 2000, 2002). While much research in this area has found that environmental risks negatively affect firm performance (Chan, Isobe \& Makino, 2008; Cuervo-Cazurra, 2006, 2008; Deephouse \& Wiseman, 2000; Habib \& Zurawicki, 2002; Lambsdorff, 2003; Makino, Isobe \& Chan, 2004; Wei, 2000a; 2000b; Veliyath \& Ferris, 1997), several studies have also shown that environmental risks, especially political risks, can also present opportunities for MNEs with the political capability to proactively manage such risks for competitive advantage (GarcíaCanal \& Guillén, 2008; Jimenes \& Delgado-Garcia, 2012). However, previous research has focused on the direct impact of environmental risks on subsidiary actions and performance through the lenses of institutional theory or transaction cost theory (e.g. Ahlstrom, Bruton \& Yeh, 2008; Chan et al., 2008; Hitt, Ahlstrom, Dacin, Levitas \& Svobodina, 2004). How MNEs respond to the external environment risks has been relatively under-explored (Makino, Lau \& Yeh, 2002). More specifically, we know relatively little about the mechanisms through which environmental risks impact subsidiary performance of MNEs.

In addition, extant research has tended to focus on how MNEs from more developed economies, such as the United States (U.S.), Europe and Japan cope with environmental risk 
when operating in host countries (Elango, 2009; Mitchell et al., 1992). However, fewer studies have examined how emerging economy MNEs (EMNEs) deal with such risks when venturing abroad. There is a need to delineate the path from environmental risks to the subsidiary performance of EMNEs, given that EMNEs originating from underdeveloped institutional environments may respond to environmental risks differently compared with established MNEs from developed countries (Luo \& Tung, 2007; Makino et al., 2002).

To address these research gaps, we adopt the resource dependence perspective (Pfeffer \& Salancik, 1978) to address the following research question: How and to what extent do localization strategies adopted by EMNEs in host countries mediate the impact of environmental risk on subsidiary performance? We propose that localization can act as an intermediate factor between environmental risks and subsidiary performance. Specifically, we focus on two aspects of localization, input localization and marketing localization, and their relationships with two environmental risks, namely political and industry risks, and subsidiary performance.

This study thus contributes to theory by extending the existing MNE literature on risk and subsidiary performance in general, and EMNEs in particular, in a number of ways. First, our research extends resource dependence theory (RDT) to understand the extent to which localization strategies mediate the impact of environmental risks on subsidiary performance. The findings from our study provide new insight into mediating mechanisms and thus contribute to theory in opening the black box of these mechanisms (Dunbar \& Ahlstrom, 1995). In particular, environmental risks' effect on resource exchanges between subsidiaries and local environments in a host country is examined through input and marketing localization strategies. By making a trade-off between autonomy and environmental dependence when facing environmental risks in host countries, EMNEs tend to use intraorganizational resources to reduce environmental dependence (Feinberg \& Gupta, 2009). 
This aspect adds to our understanding of how EMNEs in the early stage of internationalization manage environmental dependence when facing environmental risks.

Second, we further extend the concept of localization beyond staff localization by considering a wide range of input and marketing localization. This helps broaden our understanding of localization and its implications for the relationship between environmental risks and subsidiary performance. Our research demonstrates that EMNEs' localization strategies are more complex than staff localization and represent an important mechanism of resource exchanges between subsidiaries and local environments in a host country. Different levels of input and marketing localization are not only associated with subsidiary performance, but also reflect environmental risks. This aspect thus adds a new dimension to empirical research in this area. Third, we investigate whether state-owned enterprises (SOEs) and private firms have different strategic responses to environmental risks and behave differently given their different political status, and this study sheds new light on ownershiprelated performance implications in internationalization from the resource dependence perspective. Finally, this research moves beyond examining the motivation for outward FDI and entry mode selections by EMNEs by focusing on the post-entry outcomes of EMNEs, given that relatively few studies have examined these outcomes. The findings help to provide new insights into the relationship between environmental risks and the subsidiary performance of EMNEs and add much needed empirical evidence on factors such as environmental risks, input and marketing localization which affect the post-entry success of EMNEs in host countries. Subsidiary performance represents the outcome of resolving the tension between minimizing environmental risks and exploiting the advantages of localization. This study thus provides additional insight into both theory and practice with respect to multinational enterprises from emerging economies -- a sector that is of increasing importance in today's competitive landscape (Ahlstrom, 2015; Doh, McGuire \& Ozaki, 2015). 


\section{Theoretical background}

Environmental risks in host countries represent key factors affecting subsidiary performance (Elango, 2009; Jimenes \& Delgado-Garcia, 2012; Mitchell et al., 1992). This study examines two such types of risks -- political and industry risks. The former refers to the instability and incompletion of the set of laws, regulations, administrative procedures and policies formally sanctioned by the government that impact on MNE subsidiaries (CuervoCazurra, 2006, 2008; Delios \& Henisz, 2003a). The latter mainly consists of the degree of industry competition, industry growth rates, and accessibility of production inputs and human resources (Luo, 2003; Luo \& Zhao, 2009; Porter, 1990). These risks include input-market uncertainties, product-market uncertainties and competitive uncertainties, and represent the influence of customers, suppliers and competition in a host country.

Environmental risks in a host country affect the stability of the market and cost of inputs, thus reducing the profitability of MNEs that operate in the host country (Henisz, 2000; Jensen, 2006). While prior research has recognized the direct impact of environmental risks on subsidiary performance (Cuervo-Cazurra, 2006, 2008; Deephouse \& Wiseman, 2000; Elango, 2009; Habib \& Zurawicki, 2002; Jimenes \& Delgado-Garcia, 2012; Lambsdorff, 2003; Mitchell et al., 1992; Wei, 2000a; 2000b; Veliyath \& Ferris, 1997), what remains unclear is whether the strategic responses of MNEs mediate the relationship between environmental risks and subsidiary performance. Firms are not passive takers of environmental risks, and managers often adjust their strategies, such as localization, to align their subsidiary operations to the external environment in host countries. This implies that there may be a mediating path between environmental risks, localization and subsidiary performance. 


\subsection{Resource dependence theory, localization and international performance}

We adopt RDT to examine the extent to which localization strategies mediate the environment-subsidiary-performance relationship. RDT proposes that, as open systems, organizations are dependent upon external environments to access critical resources, such as financial capital, production inputs and legitimacy to operate, survive and thrive (Oliver, 1991; Pfeffer \& Salancik, 1978). Organizations are both supported and constrained by their external environments (Bruton \& Ahlstrom, 2003; Garud, Jain \& Kumaraswamy, 2002). In RDT, the external environment in host countries constitutes a source of scarce resources sought by MNEs (Moran, 1985), and a dependency situation arises when MNE subsidiaries rely on crucial resources controlled by local possessors (Pfeffer \& Salancik, 1978). 'Resources' in a broad sense include production inputs, marketing resources (e.g. distribution networks and consumer base), and information resources (Luo, 2003; Moran, 1985) as well as money. Recognizing the active agency of environmental actors (e.g. individuals, firms, groups, or governments) on organizations (Dunbar \& Ahlstrom, 1995; Garud et al., 2002), RDT theorists highlight the interdependence of firms with environmental actors and addresses how organizations respond to external environments and counteract the power of key resource holders in order to stabilize and better manage resource exchanges (Garud et al., 2002; Pfeffer, 1987). Pfeffer and Salancik (1978: 40) defined interdependence as a phenomenon that "exists whenever one actor does not entirely control all of the conditions necessary for the achievement of an action or for obtaining the outcome desired from the action."

RDT has been adopted to examine a variety of inter-organizational arrangements, such as mergers and acquisitions (M\&As), strategic alliances and long-term contracts (Casciaro \& Piskorski 2005; Deng \& Yang, 2015; Haleblian, et al., 2009; Hillman, Withers \& Collins, 2009; Pfeffer 2003; Pfeffer \& Salancik, 1978; Xia, 2010) and joint innovation (Christensen, 
1997; Wang, Ahlstrom, Nair \& Hang, 2008). These inter-organizational forms are used to mitigate external resource dependencies. Managing resource dependencies is one of the main considerations in foreign entry strategies through which organizations aim to absorb the uncertainty of resource constraints by powerful organizations that control critical resources in a foreign country (Xia, 2010). Several studies have found that forming alliances and joint ventures facilitates reliable access to the knowledge and resources of partner organizations and provides opportunities for the focal organization to learn and develop new capabilities without requiring substantial investment (Ahuja, 2000; Gulati \& Sytch, 2007; Peng \& Beamish, 2014). Similarly, M\&A is considered a mechanism for minimizing environmental dependence as this strategy enables the acquiring firm to gain desired inputs and broaden the organization's knowledge base (Cui, Meyer \& Hu, 2014; Meyer, Estrin, Bhaumik \& Peng, 2009; Deng \& Yang; 2015). Existing research also shows that inter-organizational links are dynamic so that firms not only strengthen the existing relationship with crucial resource providers, but also pursue new inter-organizational ties subsequently (Beckmen, et al., 2004; Kim, Oh \& Swaminathan, 2006; Park \& Russo, 1996). While some scholars have recognized the importance of using inter-organizational ties to manage recourse dependences, others have stated that not all resource dependency reducing strategies involve inter-organizational links with a resource-controlling organization (Lacity \& Hirschheim, 1995; Lacity \& Willcocks, 1998). The latter argue that developing internal capabilities for the supply of crucial resources represents an effective way of mitigating focal-organizational resource dependencies, as it reduces focal organizations' reliance on external parties. This represents an alternative and especially salient view about how organizations respond to resource dependencies, especially in the context of environmental risks and uncertainty.

Another stream of research on MNEs' foreign operations has recognized the importance of localization in subsidiaries' operations and has found that there is a positive 
relationship between localization and firm performance (Law, Song, Wong \& Chen, 2009; Lam \& Yeung, 2010; Selmer, 2004; Yildiz \& Fey, 2012). However, most studies have mainly focused on staff localization and the extent to which expatriate managers are replaced by local employees (Gaur, Delios \& Singh, 2007; Fryxell, Butler \& Choi, 2004; Law, Wong \& Wang, 2004). Thus, this line of research captures an incomplete account of localization which is multidimensional and is much broader than just staff localization. Subsidiaries depend not only on a host country's human resources for local production, but also on marketing and information resources for local operations, adaptation and expansion. Even with the support of its corporate parent, a subsidiary still relies on some country-specific, non-substitutable resources for local market expansion (Gaur, Delios \& Singh, 2007). Rangan \& Drummond (2011) emphasize the importance of both input localization and output localization (though they use the term 'output adaptation') in explaining subsidiary performance and propose that appropriate localization strategies are crucial when subsidiaries face external uncertainty in host countries.

While existing studies have enhanced our understanding of the role of resource dependencies and localization in MNEs' foreign operations, few studies have extended the resource dependence logic to examine the relationship between environmental risks, localization and subsidiary performance. Thus, the tension between minimizing environmental risks and exploiting the advantages of localization has not been systematically examined. Environmental risk may affect the degree of resource exchange between subsidiaries and local firms and induce EMNEs to rebalance environmental dependence using localization strategies (Gulati \& Sytch, 2007). Employing a RDT logic, localization constitutes a distinct means to minimize external risks through altering a subsidiary's dependence on resources held by external actors. In other words, a subsidiary may reduce its vulnerability by adjusting the degree of localization and decreasing its interest in valued local 
resources. In particular, when external environmental risks are high or difficult to absorb, internal resource flows between the parent firm and subsidiaries may replace interorganizational resource exchange (Feinberg \& Gupta, 2009; c, 1991; Lacity \& Willcocks, 1998). Building on RDT, we argue that industry and political risks will induce firms to adjust the degree of localization to align their operations to the external environment. Different degrees of localization are associated with different levels of access to local resources in a host country which have different performance implications. This implies that the level of environmental risk is reflected in the extent of input and marketing localization which in turn affects subsidiary performance. As such, input and marketing localization mediate the environmental risk and performance relationship as shown in Figure 1.

\section{[INSERT FIGURE 1 ABOUT HERE]}

\section{The mediating path for environmental risks}

\subsection{Input Localization}

When a local environment becomes risky, MNEs operating in such an environment are subject to increasing uncertainty. Environmental risks, either political risks or industry risks, curb MNEs' willingness to increase their dependence on local suppliers (Yildiz \& Fey, 2012). Where policy credibility is low, firms minimize commitments to a market, or avoid investment (Delios \& Henisz, 2003b; Henisz \& Delios, 2001). As risks increase in host countries, heavy reliance on local resources may result in uncertainties and pose significant challenges and costs on MNE subsidiaries. Therefore, MNEs may respond to environmental risks by altering input localization and reducing their exposure and reliance on local resources, and search for alternative ways of obtaining scarce resources (Kostova, Roth \& Dacin, 2008; Pfeffer \& Salancik, 1978; Yildiz \& Fey, 2012). Luo (2003) adds that subsidiaries can ease their dependence on local suppliers by increasingly drawing resources from an MNE's multi-unit system, thereby reducing unpredictable risks associated with 
acquiring resources locally. Thus, a reduced level of input localization may become an important strategic response when facing a high level of environmental risks, especially in host countries with institutional ambiguities, underdeveloped markets and ineffective regulation enforcement (Wright, Filatotchev, Hoskisson \& Peng, 2005).

The parent firm is considered one of the most important resource providers that a subsidiary can rely on when managing and minimizing environmental risks (Chang \& Taylor, 1999; Luo, 2003). Through internal intra-organizational resource flows, subsidiaries can control crucial resources when facing environmental uncertainty, thereby reducing resource dependence on the external resource holders (Lacity \& Hirschheim, 1995; Lacity \& Willcocks, 1998; Ulrich \& Barney, 1984). In this sense, the intra-organizational resource flows become a risk reduction mechanism through which EMNEs' subsidiaries can minimize their exposure to environmental risks and alleviate external dependence in a risky host country (Feinberg \& Gupta, 2009; Kobrin, 1991; Ring, Lenway \& Govekar, 1990).

Although a low level of input localization can reduce MNEs' exposure to local environmental risks, it will in turn affect local subsidiaries' performance and lead to the loss of potential benefits associated with input localization for a number of reasons. First, a low level of input localization can increase a subsidiary' logistic costs and reduce efficiency. The subsidiary is also unable to draw on scarce resources that are unavailable internally (Hennart, 2012). Adopting such an avoiding approach, subsidiaries may reduce repeated local sourcing. Thus, MNEs are unable to access complementary local resources, as it is easier to access local resources if MNEs frequently contact local suppliers and are embedded in the local supply network (Rangan \& Drummond, 2011). Second, a subsidiary with a reduced level of local human resources may lack local business networks since ties with local businesses are not easily obtained without the involvement of local managers and employees (Selmer, 2004; Law et al., 2009). The parent company of MNE subsidiaries can use expatriates instead of 
capable locals in order to maintain independence (Ahlstrom, Bruton \& Lui, 2000). However, such a strategy results in limited participation in production and management by local people, which can negatively affect subsidiary performance, given that local managers have better knowledge of the local market environment (Fryxell, Butler \& Choi, 2004; Lam \& Yeung, 2010). Finally, with a low level of localization, an MNE will reduce its strategic commitment to the host country through decreased local sourcing. Reducing commitment may lead to a lack of local support and symbolic resources, such as legitimacy from the host country government and local communities (Ahlstrom et al., 2008). This strategy may also result in negligible contributions to the host country in terms of local employment, knowledge spillovers and related industries. The subsidiary may be treated as an outsider (Eden \& Miller, 2004). Being an outsider may incur the negative effect of liability-of-foreignness, thus reducing subsidiary performance (Law et al., 2009).

It should be noted that there is a counterargument that firms may increase the level of input localization to counter balance the environmental risks, such as by choosing joint ventures as an entry mode or forming strategic alliances with local partners (Hitt et al., 2000; Khanna \& Rivkin, 2001). Such arrangements enable firms to gain access to local knowledge and contacts, and share environmental risks with local partners. However, the argument does not fully reflect the cost of increasing localization in a volatile environment or the ability needed to manage a high level of localization (Feinberg \& Gupta, 2009; Kobrin, 1991; Meyer \& Estrin, 2001; Ring, Lenway \& Govekar, 1990). Volatility in the political and industrial environment in a host country may make it impossible for a subsidiary to anticipate all contingencies (Luo, 2003). High environmental risks are likely to jeopardize a subsidiary’s operations and may hinder the subsidiary's ability to enforce cooperative agreements with local partners (Brouthers \& Hennart, 2007; Feinberg \& Gupta, 2009), leading to higher transaction costs when EMNEs rely on local resources. As such, subsidiaries may be 
constrained in pursuing business opportunities if business transactions with local suppliers and distributors are not effectively protected due to environmental risks (Acemoglu \& Johnson, 2005; Guler \& Guillén, 2010). For example, contracts with local suppliers or distributors may not be enforced or local suppliers may unreasonably delay delivering raw materials needed for operations (Feinberg \& Gupta, 2009; Lacity \& Hirschheim, 1995; Lacity \& Willcocks, 1998; Luo, 2003). As a result, EMNEs may prefer to use intra-organizational resource flows to replace the inter-organizational relationship (Gulati \& Sytch, 2007). Through the reduction of localization, EMNEs can reduce exchange uncertainty with local partners.

Moreover, forming a partnership may create a dilemma due to interdependence and a loss of autonomy (Das \& Teng, 2002). Such a strategy also requires a firm to have the ability to manage the inter-organizational relationship effectively. However, EMNEs lack experience in managing partner relationships in the early stage of internationalization and may be cautious about local partners' intentions and commitment when facing high environmental risks. Hence, they are more likely to depend on their corporate parent for resources, or operate as an independent system in order to maintain their autonomy and independence (Lu, et al., 2014; Wang, et al., 2012).

Finally, although transferring resources and knowledge between the parent firm and the subsidiary incurs cost (Hansen, Mors \& Løvas, 2005; Jensen \& Szulanski, 2004), the cost and challenges associated with such a transfer is lower than inter-organizational resource exchange as the former share an organizational identity and have common corporate objectives which help facilitate resource flows and reduce the complexity of resource exchange (Venaik, Midgley \& Devinney, 2005; Zhao \& Anand, 2009). Thus, utilizing a multi-unit system to transfer resources and knowledge within the MNE is a particularly attractive and feasible strategy for EMNEs that lack international experience to manage inter- 
organizational resource exchange in host countries (Elango \& Pattnaik, 2007). In this regard, EMNEs' overseas subsidiaries may choose a lower level of input localization and rely on the headquarters to act as a resource provider and risk reduction mechanism.

In summary, high environmental risks reduce the commitment of MNEs to input localization or push MNEs to reduce local exposure or dependence on local resources in order to maintain their organizational autonomy and stability in the volatile environments. This results in the loss of the benefits associated with input localization. This loss of benefits derived from input localization subsequently curbs subsidiary performance in local markets. Thus, we hypothesize:

H1a: Input localization mediates the relationship between industry risks in host countries and subsidiary performance, in that industry risks negatively affect the level of input localization, and the reduction in input localization leads to a decrease in subsidiary performance.

H1b: Input localization mediates the relationship between political risks in host countries and subsidiary performance, in that political risks negatively affect input localization, thus reducing subsidiary performance.

\subsection{Marketing Localization}

A similar rationale can be applied to the mediating role of marketing localization. Marketing localization is akin to local responsiveness and refers to the extent to which MNEs operate foreign subsidiaries according to local norms, adapt products to suit local tastes, localize a corporate image and become socially embedded in local networks (Rangan \& Drummond, 2011). This strategy requires adaptations to local consumer needs, thus escalating interactions 
with the host market. With high environmental risks, MNEs are less willing to commit to a high degree of marketing localization, especially in the early stages of investment (Figueirade-Lemos, Johanson \& Vahlne, 2011). This is because a large number of resources, such as experienced personnel, is needed for successful marketing localization in highly risky environments where conditions change rapidly (Lam \& Yeung, 2010; Waldman, Ramirez, House \& Puranam, 2001), thereby increasing MNEs' operational costs in host countries. Furthermore, high environmental risks not only reduce MNEs' willingness to commit to marketing localization, but also create difficulties in executing the marketing localization strategy. In particular, firms from emerging economies may lack the knowledge and experience needed for implementing marketing localization in host countries (Guillén \& Garcia-Canal, 2009; Meyer, Mudambi \& Narula, 2011), thereby putting additional hurdles in achieving successful local adaptation (Figueira-de-Lemos et al., 2011). In particular, a risky industry environment impairs a firm's ability to locally source inputs or value chain activities, thus increasing operational costs and managerial overheads in the process of organizational control (Oliver, 1991). This may decrease firms' marketing localization.

The above discussion implies that a high risk environment may push an MNE subsidiary to reduce the degree of marketing localization, which then leads the subsidiary to decrease its dependence on host country resources and reduce its exposure to host country environments. Such a strategy helps to reduce its vulnerability to the risky environment of a host county. However, a decrease in marketing localization because of high environmental risks can adversely influence the performance of a subsidiary since marketing localization can be utilized as a means to enhance subsidiary performance. Marketing localization enables an MNE to be more accepted locally by behaving more like a local firm through marketing and product adaptation (Eden \& Miller, 2004). In particular, adaptation to the cultural values, needs and expectations of local customers increases local acceptance of MNEs' products or 
services and, thereby, increases the possibility of successful operations in host countries (Yildiz \& Fey, 2012). Marketing localization is also a key strategy for firms to gather local market knowledge and build closer linkages with local suppliers and customers (Andersen, 2013; Gertler, 2003). It helps to avoid the misunderstanding of local demand conditions and has positive operational implications. Therefore, when high environment risks reduce the level of marketing localization, firms lose the potential benefits discussed above, which may hinder their subsidiary performance. Our discussion leads to the following hypotheses:

H2a: Marketing localization mediates the relationship between industry risks in host countries and subsidiary performance, in that industry risks negatively affect the level of marketing localization, and the reduction in marketing localization leads to a decrease in subsidiary performance.

H2b: Marketing localization mediates the relationship between political risks in host countries and subsidiary performance, in that political risks negatively affect marketing localization, thus reducing subsidiary performance.

\section{The moderating effect of ownership}

Firms are shaped by the home context from which they originate (Holburn \& Zelner 2010; Meyer et al., 2011). As such, a firm's capability and resource endowments developed in their home country affect their strategic responses to environmental risks when operating in a host country. It is recognized that organizational practices and capability vary with ownership (Li \& Xia, 2008) and so different ownership results in different levels of political support and legitimacy (Peng \& Luo, 2000). SOEs differ from private firms in terms of the organizational structures, management systems and resource endowments (Wright et al., 2005). The different characteristics of SOEs and private firms may lead to different strategic 
responses to environmental risks and hence result in different subsidiary performance (Lin, 2010; Peng, 2003; Wright et al., 2005).

SOEs are both economic and political actors and operate in a highly regulated environment controlled by their home country government. Their special position has implications for their response to environment risks when operating in foreign countries. First, from the resource dependency perspective, SOEs are able to draw on resources from their home government or receive preferential treatment due to their political status and a close relationship with the home country government, especially when dealing with political risks in foreign operations (Luo, Xue \& Han, 2010). Home government support can result in resource advantages and alters the extent to which environmental risks influence foreign operations. In this sense, SOEs may be more risk tolerant than their counterparts i.e. private firms (Cui \& Jiang, 2012). The close relationship between SOEs and the home country government also enables SOEs to obtain superior access to timely and accurate information on policy interpretations and changes (Bruton, Peng, Ahlstrom, Stan \& Xu, 2015). These can help SOEs anticipate changes in the policy environment and thus better prepare to respond to political risks (Schuler, Rehbein \& Cramer, 2002). Second, burdensome government intervention at home provides SOEs with a training ground for dealing with environmental and political changes in a host country (Morck, Yeung \& Zhao, 2008). Chinese SOEs, for example, have considerable experience of dealing with complex and under-developed institutions through frequently interacting with the home country government (Bruton et al., 2015; Bruton, Ahlstrom \& Yeh, 2004). They can draw upon their accumulated experiences in responding to political risks when operating in a host country.

In contrast, private firms are less supported by the home country government than their SOE counterparts. Private firms often directly face fierce competition in the domestic market, forcing them to be more flexible and efficient in their operations (Lin, 2010). In particular, 
competing in unfavorable market conditions, private firms may have developed market-based capabilities by mainly following market principles and seeking commercial interests. They are less likely to be vulnerable to industry risks than SOEs (Lu, Liu \& Wang, 2011).

In summary, it is anticipated that SOEs are able to counterbalance the political risks in host countries due to their close attachment to their home country government. Indeed, political resources enable SOEs to mitigate political risks more effectively than private firms. Unlike SOEs, private firms have a low level of political resources and are less able to rely on the home country government to reduce the level of political risks in host countries. Thus, political risks may have a more negative impact on the level of localization of private firms than that of SOEs. However, SOEs that have evolved in an environment that is subject to government intervention may lack market-based capability compared with private firms ( $\mathrm{Li}$ \& Xia, 2008). Therefore, industry risks may have a more negative impact on the level of localization of SOEs than private firms. Hence, we hypothesize:

H3a: State ownership moderates the extent to which input localization mediates the relationship between industry and political risks and subsidiary performance in host countries.

H3b: State ownership moderates the extent to which marketing localization mediates the relationship between industry and political risks and subsidiary performance in host countries.

\section{Methods}

\subsection{Sample and Data Collection}

The data used in this study was collected through collaboration with the Asia Pacific Foundation of Canada (APFC) and the China Council for the Promotion of International

Trade $(\text { CCPIT })^{1}$. Such collaboration allowed us to access the networks of the APFC and 
CCPIT. Previous surveys on China's outward FDI conducted by the CCPIT and APFC have been widely cited (e.g., Luo, Xue \& Han, 2010; Tung, 2007; UNCTD, 2006).

We first developed the survey questionnaire in English and then, with the assistance of independent translators, the questionnaire was translated into Chinese, and finally translated back to English to ensure conceptual equivalence (Hoskisson, Eden, Lau \& Wright, 2000). We conducted four in-depth interviews with CCPIT officials to validate our measurements and then modified a few questionnaire items based on the feedback from our interviews. We also trialed the questionnaire with ten senior managers who were in charge of outward FDI in the CCPIT's membership enterprises and further revised the questionnaire according to their feedback.

We compared the CCPIT's membership enterprises list with that of Chinese firms that registered their outward FDI activities with China's Ministry of Commerce (MOFCOM) to identify Chinese firms that have actively engaged in outward FDI. The latter list was considered the most comprehensive list of Chinese firms that have outward FDI activities (Cui \& Jiang, 2012). A total of 2,000 firms were randomly chosen due to cost and administrative constraints. These firms were CCPIT's membership enterprises and also on the MOFCOM's registration list for their outward FDI activities.

The headquarters of the CCPIT in Beijing received a total of 365 completed questionnaires, representing a response rate of $18.25 \%$. We found 32 completed questionnaires contained basic information which was inconsistent with that on the CCPIT's membership enterprises database. Thus, these 32 firms were deleted from the data, resulting in 333 verified questionnaires, representing a response rate of $16.7 \%$. We also randomly checked 20 respondents via telephone to confirm that the questionnaire was completed by senior managers who were familiar with their firms' internationalization activities. We also compared location and industries between the responding firms and non-responding ones and 
found these two groups of firms have similar distribution patterns in industries and location ${ }^{2}$. Foreign wholly-owned subsidiaries in China were dropped from the sample, given our focus on the overseas subsidiary performance of Chinese firms (Yiu, Lau \& Bruton, 2007). Our final sample consisted of 206 Chinese firms, among which 55 are SOEs and 151 are private firms in 14 different industries and investing in 58 foreign countries.

\subsection{Variables and Measurements}

\subsubsection{Dependent variable}

Similar to previous studies (He, Tian \& Chen, 2007; Lu et al., 2010; Woodcock, Beamish \& Makino, 1994), this study adopted the same perceptual measure for the subsidiary performance of Chinese MNEs. This self-evaluation approach was appropriate because (1) firms were either unwilling or unable to provide sensitive accounting data (e.g. performance); (2) variations in accounting standards across countries reduced the comparability and/or (3) there were fluctuations in exchange rates between home and host countries (He et al., 2007; Woodcock et al., 1994). Although difficulties such as self-enhancement and objectivity might be encountered, self-evaluated surveys have been proved to possess strong internal consistency and reliability (Cooper \& Artz, 1995; Ketokivi \& Schroeder, 2004) and have been widely used in previous studies (Andersson, Forsgren \& Holm, 2002; Birkinshaw, Hood \& Young; 2005; He et al., 2007; Lu et al., 2010).

We asked respondents to evaluate the performance of the most recently established overseas subsidiaries. Focusing on these recently established subsidiaries has a few advantages. First, respondents can more easily identify the focal overseas subsidiary from other overseas subsidiaries, and thus increase the reliability of the self-evaluated measures. Second, all other key independent variables, i.e. environment risks, input localization, and marketing localization, are based on questions on the focal overseas subsidiary. Thus, the 
dependent variable and the key independent variables are all about the same overseas subsidiary.

Three seven-point Likert-scale items (1=very dissatisfied; 7=very satisfied $)$ were used to capture managers' perception of the performance of their most recently established overseas subsidiaries, including the extent of managers' satisfaction in terms of the growth rate of sales, growth rate of market share and growth rate of profit in their overseas subsidiaries. Based on these components, we used factor analysis to construct a proxy for the subsidiary performance of the sample firms, given that newer subsidiaries, in particular, may be loss-making or have little revenue since they are in the early stages of developing a market presence (Dai \& Liu, 2009). Therefore, a manager's satisfaction with the growth rate is a fundamental measure of subsidiary performance (Cooper \& Artz, 1995).

\subsubsection{Independent variables}

Based on previous research (Luo \& Zhao, 2009) and the evaluation and practical insights of the managers in our pilot study, we developed five seven-point Likert scale items to capture the extent to which managers perceive host country industry risks in terms of: (1) level of industrial competition, (2) availability of inputs, raw materials and components, (3) prices of inputs, raw materials and components, (4) availability of human resources, and (5) availability of financial capital.

In measuring political risks, we employed an objective measurement, the World Governance Index (WGI) in 2010, which has been widely adopted in previous studies to capture host country political risks (Cuervo-Cazurra \& Genc, 2008; Slangen \& van Tulder, 2009). The WGI reports governance indicators for 215 economies from 1996 to 2012 and covers six dimensions of governance: voice and accountability, political instability and absence of violence, government effectiveness, regulatory quality, rule of law, and control of corruption (Kaufmann, Kraay, Mastruzzi, 2008). As each dimension has been constructed by 
compiling a number of primary and secondary data sources, the index offers reliable and comprehensive proxies for empirical studies (Oh \& Oetzel, 2011).

\subsubsection{Mediating variables}

While international business studies have addressed the concept of localization, especially from the human resource perspective (e.g. Ahlstrom, Bruton \& Chan, 2001; Law et al., 2004; 2009; Lam \& Yeung, 2010), few studies have developed measurements for localization. Based on the existing literature and our pilot study mentioned above, we developed three seven-point Likert scale items to measure firms' input localization. We asked the respondents to indicate the extent to which their overseas subsidiaries have acquired: (1) local raw materials and components; (2) local human resources; and (3) local financial capital.

Marketing localization has been identified as an important element of a firm's global strategy. Based on prior studies (Law et al., 2009), we developed three seven-point Likert scale items to ask the respondents to indicate the extent to which their overseas subsidiaries have: (1) adapted to local business culture; (2) adapted to local customers' needs; (3) developed local networks and partnerships.

\subsubsection{Control variables}

We included four control variables which may affect international performance, namely firm age (Fang, Wade, Delios \& Beamish, 2007; Zhou, Wu \& Luo, 2007), firm size (Lu et al., 2010; Luo \& Peng, 1999), local experience (Fang et al., 2007) and entry mode. The four variables are measured by the number of years since founding, the number of employees, the number of years of overseas subsidiaries operating in host countries, and whether a firm has chosen green field FDI as the entry mode. 


\section{Results}

We employed a structural equation modeling (SEM) approach which avoids problems of overestimation and underestimation of mediation effects by controlling for measurement errors (Hoyle \& Smith, 1994). This method is most suitable to our study as it examines the mediation effects of localization on the relationship between environmental risks and international performance.

\subsection{Validity and reliability of the constructs}

To minimize the effect of common method variance, we took the following steps. First, multiple item constructs were used in our survey, since response biases are more likely to occur at the item level than at the construct level. In addition, our main hypotheses involve mediating effects. It is observed that complex relationships between the dependent and independent variables are not part of the respondents' theory-in-use (Chang, van Witteloostuijn \& Eden, 2010). This helps reduce the risks of common method variance. Furthermore, we used an objective measurement for one of the independent variables (political risk) which helps to avoid common method variance since the dependent variable is constructed using information from different sources than the independent variable (Chang, et al., 2010). Finally, we conducted Harman's single-factor test and found that the single factor model demonstrated a poor fit to the data (Podsakoff \& Organ, 1986). Thus, common methods bias is not a major threat to the subsequent hypothesis testing. Table 1 shows the descriptive statistics.

\section{[INSERT TABLE 1 ABOUT HERE]}

We tested the construct composite reliability (CR), convergent and discriminant validity of the constructs in accordance with accepted practice. The CR values for all constructs were good, ranging from 0.6 to 0.98 . The five-factor confirmatory factor analysis 
(CFA) model provided a good overall fit with the data, with all indices meeting the respective criteria: $\chi 2(142)=313.165, \mathrm{p}<0.001 ; \mathrm{NNFI}=0.94 ; \mathrm{CFI}=0.95 ; \mathrm{RMSEA}=0.078 ; \mathrm{SRMR}=0.084$. Table 2 presents the CFA results, which indicate good convergent validity. The average variance extracted (AVE) and the square of the correlations between constructs are listed in Table 3. Discriminant validity is established if the AVE is larger than the squared multiple correlation coefficients between constructs. Our results demonstrate the fulfilling of this criterion, thus providing strong support to discriminant validity. Hence, the measurement scales used in this study were found to be reliable and valid.

\section{[INSERT TABLE 2 AND TABLE 3 ABOUT HERE]}

\subsection{Hypothesis tests}

The mediation effect is tested by comparing the goodness-of-fit of the direct effect model with that of a full predictor-mediator-outcome mediation model which has no direct path from the predictor to the outcome and a partial mediation model which has freely estimated a direct path from the predictor to outcome. Table 4 summarizes the results of the mediation tests. M1 is a direct effect model with both risk constructs and both localization constructs directly linked to subsidiary performance. The fit indices of M1 signal a poor overall fit: $\chi^{2}=260.21, \mathrm{df}=28 ; \mathrm{NNFI}=0.13 ; \mathrm{CFI}=0.32 ; \mathrm{RMSEA}=0.204 ; \mathrm{SRMR}=0.161 . \mathrm{M} 2$ presents the results of the partially mediated model, where industry risks and political risks are linked to input localization and marketing localization. M2 represents a significant improvement of M1. However, the overall goodness-of-fit indices $\left(\chi^{2}=66.46, \mathrm{df}=24\right.$; $\mathrm{NNFI}=0.81 ; \mathrm{CFI}=0.88 ; \mathrm{RMSEA}=0.094 ; \mathrm{SRMR}=0.079)$ indicate that further modifications are needed.

\section{[INSERT TABLE 4 ABOUT HERE]}

M3 represents a full, partially mediated model, where an additional mediating path from marketing localization to input localization was added to M2. This has further improved 
a good overall fit: $\chi^{2}=49.34, \mathrm{df}=23 ; \mathrm{NNFI}=0.88 \mathrm{CFI}=0.92 ; \mathrm{RMSEA}=0.076 ; \mathrm{SRMR}=0.073$. M4, a full mediation model, was estimated, where each direct path between both risk constructs and performance in M3 was constrained to zero. The findings reveal that the fit indices of M4 were good and similar to those of $\mathrm{M} 3: \chi^{2}=54.92, \mathrm{df}=25 ; \mathrm{NNFI}=0.87 ; \mathrm{CFI}=0.91$; RMSEA $=0.077 ;$ SRMR $=0.075$. We further tested M5 and M6, each with one direct effect from environmental risks to subsidiary performance. M5 is a partial mediation model with the direct effect from political risk to performance, and the findings reveal better fit indices: $\chi^{2}=49.91, \mathrm{df}=24 ; \mathrm{NNFI}=0.89 ; \mathrm{CFI}=0.92 ; \mathrm{RMSEA}=0.073 ; \mathrm{SRMR}=0.073 . \mathrm{M} 6$ is a partial mediation model with the direct effect from industry risk to performance with slightly worse fit indices: $\chi^{2}=54.43, \mathrm{df}=24 ; \mathrm{NNFI}=0.87 ; \mathrm{CFI}=0.91 ; \mathrm{RMSEA}=0.080 ; \mathrm{SRMR}=0.075$. The results are consistent with previous research which has long argued for the impact of political risks on subsidiary performance (e.g. Cuervo-Cazurra, 2006, 2008; Deephouse \& Wiseman, 2000; Habib \& Zurawicki, 2002; Lambsdorff, 2003; Wei, 2000a; 2000b; Veliyath \& Ferris, 1997). Since M4-6 do not improve the overall fit of M3, M3 is chosen as the baseline model for further assessment of the hypotheses.

\section{[INSERT FIGURE 2 ABOUT HERE]}

Figure 2 illustrates the standardized parameter estimates for M3 (the full partial mediation model). Hypothesis 1a stated that input localization mediates the relationship between industry risks and subsidiary performance. As shown in Figure 2, the hypothesized path from industry risks to input localization is negatively significant $(\beta=-1.12, p<0.001)$, and the path from input localization to performance is also significant $(\beta=0.16, p<0.01)$. Hypothesis $2 \mathrm{a}$ stated that marketing localization mediates the relationship between industry risks and performance. Similar to Hypothesis 1a, the paths from industry risks to marketing localization $(\beta=-0.29, \mathrm{p}<0.01)$ and from marketing localization to performance $(\beta=0.44$, 
$\mathrm{p}<0.001)$ are both statistically significant. Thus, Hypothesis 1a and Hypothesis $2 \mathrm{a}$ are strongly supported.

Hypothesis $1 \mathrm{~b}$ and Hypothesis $2 \mathrm{~b}$ held that input localization and marketing localization mediate the relationship between political risk and subsidiary performance respectively. As shown in Figure 2, although there is a significant relationship between input and marketing localization and subsidiary performance, the relationships between political risks and input localization $(\beta=0.04$, i.s. $)$ and marketing localization $(\beta=0.14$, i.s. $)$ are not statistically significant. Therefore, Hypothesis $1 \mathrm{~b}$ and Hypothesis $2 \mathrm{~b}$ was not supported. However, the findings show a direct statistically significant path from political risk to subsidiary performance $(\beta=0.14, \mathrm{p}<0.05)$.

Furthermore, the findings also demonstrate a statistically significant path from marketing localization to input localization $(\beta=0.22, \mathrm{p}<0.001)$. This indicates that the mediating effect of marketing localization on the subsidiary performance of Chinese firms is partially channeled through input localization. It may indicate that marketing localization contributes positively to the extent of input localization which in turn leads to an improvement in international performance.

\subsection{The moderating effect of ownership}

In order to account for the moderating impact of ownership, a multi-group analysis was performed to test $\mathrm{H} 3 \mathrm{a}$ and $\mathrm{H} 3 \mathrm{~b}$. Table 5 reports the results of multiple-group analysis based on ownership: SOEs and private firms. The overall fit indices $\left(\chi^{2}=67.21, \mathrm{df}=46\right.$; NNFI $=0.90$; $\mathrm{CFI}=0.94$; RMSEA $=0.048$ ) suggest that the baseline model (the full partial mediation model M3) fits the data well across both groups of firms. We compared the baseline model with a series of nested models by constraining the relevant coefficients of the paths as equal across both groups. For each nested model (M3-1 to M3-9 in Table 5), when $\Delta \chi^{2}$ is statistically significant, it indicates that the assumption that the coefficient of the constrained path is the 
same for SOEs and private firms is rejected, which means ownership has a moderating effect on this path.

\section{[INSERT TABLE 5 ABOUT HERE]}

The results partially support $\mathrm{H} 3 \mathrm{a}$ which proposes that state ownership moderates the extent to which input localization mediates the relationship between industry and political risks and performance. The results show that state ownership significantly affects the paths from industry risks to input localization. By further comparing the standardized coefficients in Table 5, we find that industry risks have a more negative impact on the input localization of SOEs $(\beta=-1.36, \mathrm{p}<0.001)$ than that of private firms $(\beta=-1.03, \mathrm{p}<0.001)$.

\section{Discussion}

This paper has examined whether input localization and marketing localization mediate the impact of political risks and industry risks on subsidiary performance, and the moderating effect of state ownership on this mediation mechanism based on a sample of Chinese MNEs. The results indicate that localization strategies mediate industry risks, but have no mediating effect on the link between political risks and subsidiary performance. These findings suggest that the impact of industry risks on subsidiary performance is channeled through input and marketing localization. However, political risks do not affect the level of localization, but have a positive effect on Chinese MNEs' overseas performance directly. The findings imply that host country industry risks have a significant negative impact on Chinese MNEs' overseas subsidiary performance channeled through reducing the level of localization, and Chinese MNEs tend to use internal resource flows to reduce environmental dependence when they operate in risky industries in host countries. The results indicate that those MNEs originating in an under-developed institutional environment with incomplete marketization are more able to deal with political risks than industry risks. 
The findings further show that Chinese MNEs are more likely to choose a higher level of marketing localization than input localization, given the level of industry risks. This may be because of the stage of Chinese MNEs' internationalization. With an average subsidiary age of three years, the majority of the sample firms are still in the early stages of outward FDI, and the tangible commitment of these firms to local markets, reflected in input localization, is relatively low when environmental risks are high. This is consistent with the proposition put forward by Figueira-de-Lemos et al. (2011) that under high environmental risks, a firm's commitment is low because of uncertainty, especially its commitment in a tangible form (input localization), and its limited commitment is reflected by mainly making intangible commitments, which is captured by marketing localization in this study.

Furthermore, the paper has found that the mediating effect of marketing localization on subsidiary performance is partially channeled through input localization. This indicates that marketing localization contributes positively to the extent of input localization which in turn leads to an improvement in subsidiary performance. When firms accumulate more knowledge about the local market and understand potential opportunities through marketing localization (Figueira-de-Lemos et al., 2011, Johanson \& Vahlne, 2006), they increase their commitment to the foreign market in a more tangible way through input localization in order to capitalize on the potential opportunities.

Contrary to the majority of previous studies (e.g. Cuervo-Cazurra, 2006, 2008; Deephouse \& Wiseman, 2000; Habib \& Zurawicki, 2002; Lambsdorff, 2003; Wei, 2000a; 2000b; Veliyath \& Ferris, 1997), this study reveals that Chinese MNEs tend to perform better in countries with higher political risks. The positive relationship between political risk and performance indicates that EMNEs may be able to proactively exploit the opportunity associated with political risk (Jimenez \& Delgado-Garcia, 2012; Kozhikode \& Li, 2012), given that they have accumulated political capabilities when operating in their home country 
with the under-developed institutional environment. China has gone through dramatic political and economic change in the past few decades, which has provided a training ground for Chinese firms to accumulate experience and build capabilities in dealing with unpredictable environments (Ahlstrom, Levitas, Hitt, Dacin \& Zhu, 2014). Such experiences and capabilities developed at home can be exploited by these firms when operating in a host country with high political risks (Morck et al., 2008).

The results of testing ownership effect (presented in Table 5) further reveal the difference between SOEs and private firms in managing environmental risks. Chinese SOEs are more vulnerable to industry risks through localization strategies. At the same level of industry risks, SOEs have a lower level of commitment to locally sourcing their inputs than that of private firms. The results imply that SOEs are less able to deal with industry risks in host countries due to a lack of flexibility and the ability needed to acquire local resources under industry risks.

\subsection{Contributions}

This study makes three contributions to the existing literature. First, unlike previous research which either emphasized the impact of environmental risks or localization on performance in isolation, this study extends the resource dependence logic to examine interconnections between environmental risks, localization and subsidiary performance. This helps provide new insights into how EMNEs balance environmental dependence in responding to environmental risks in host countries. The findings enhance our understanding of the mechanisms through which the effect of environmental risks on subsidiary performance is realized and thus fill an important research gap on firms form emerging economies (cf. Young, Tsai, Wang, Liu \& Ahlstrom, 2014). Specifically, we bridge two streams of literature on environmental risks and localization. In the established literature, localization is linked to the choice of entry modes, the deployment of local personnel in the 
top management team of the subsidiary, and imitation of local practices (Fryxell et al., 2004; Law et al., 2009; Lam \& Yeung, 2010). Few studies have examined the mediating effect of localization strategies on the relationship between environmental risk and subsidiary performance. On the other hand, in the literature on environmental risks and MNEs, researchers often focus on the direct link between environmental risks and performance by treating the mechanism through which environmental risks affect subsidiary performance as a black box. Departing from prior research, we go beyond the direct links postulated in existing studies by explicitly examining the mediating path among these factors. In so doing, this study advances our understanding of how EMNEs alter their localization strategies and use intra-organizational resource flows to reduce environmental dependence when facing risks in host countries.

Second, we move beyond the traditional focus on staff localization and further delineate localization into input and marketing localization. Our study explicitly demonstrates that input and marketing localization are important factors which mediate the relationship between industry risks and subsidiary performance. Hence, our research helps capture the complexity of localization and shed new light on the importance of localization strategies in subsidiary performance from the resource dependence perspective.

Third, considering the moderating effect of ownership on the relationship between environmental risks and localization, we found that the impact of environmental risks is contingent on firm ownership. Industry risks have a stronger negative impact on the extent of localization of SOEs than that of private firms. Private firms may have established marketbased capabilities which help them to cope with commercial risks in international operations, whereas SOEs that rely on government support instead of market-based capabilities at home are less able to deal with industry risks in host countries. Our analysis suggests that EMNEs carry the baggage embedded in their home country even when they operate abroad. The 
ownership status which is associated with the availability of resources and support from the home country government affects firms' responses to environment risks when operating in foreign countries. This evidence broadens our understanding of how the relationship between environmental risks and performance is shaped by EMNEs' home context through ownership.

\subsection{Managerial relevance}

Our findings have a number of managerial implications and provide managers with a better understanding of mechanisms through which environmental risks affect subsidiary performance. First, our findings show that both input and marketing localization are important mediators linking industry risks and subsidiary performance. Because of the negative relationship between industry risks and localization, and the positive relationship between localization and performance, firms are able to achieve a higher level of performance in less risky industries in host countries. In order to capitalize high-risk/highreturn expectations, managers should commit more to both input and marketing localization in responding to higher industry risks. By breaking the negative association between industry risks and localization, firms can benefit more from localization, thereby achieving better subsidiary performance.

Second, our findings show that SOEs are more vulnerable to industry risks in host countries, while political risks do not deter their localization strategies. This suggests that SOEs managers need to have a better understanding of industry risks in order to respond to such risks appropriately in host countries, and can achieve successful international operations by minimizing industry risks through different configurations of input and marketing localization. Managers of SOEs need to develop market-based capabilities and accumulate international experience in order to implement localization strategies effectively when dealing with industry risks. Managers should also build an understanding of the mechanisms through which SOEs can seek to balance autonomy and environmental dependencies (Stan, 
Peng \& Bruton, 2014). They may need to step out their comfort zone and learn how to manage partner dependence in dealing with industry risks in host countries.

Third, Chinese MNEs are able to achieve a higher level of performance in host countries with higher political risks, which indicates that they have developed political capabilities at home to deal with uncertainties in the political sphere. Future Chinese MNEs can utilize the domestic market as a training ground to build up their political capabilities before investing in countries with high political risks. As for those investing in more political stable countries, Chinese MNEs may need to develop more market-oriented capabilities in order to achieve a higher level of performance as they have fewer opportunities to exploit their political capabilities in such host countries.

\subsection{Limitations and future research}

Our study has some limitations which represent avenues for future studies. First, we only use a perceptual measure for subsidiary performance. Future studies could use objective measures to compare how localization and environmental risks affect different dimensions of subsidiary performance. Second, our study is based on a sample of Chinese MNEs; further research is needed to examine whether our findings can be generalized in other emerging economy contexts. Third, our study only focuses on the environmental risks in host countries. Future study could further explore institutions in both home and host countries, as well as political relations between the two, which has been previously linked to the motivation of foreign investment of EMNEs, to provide a holistic picture of the impact of external environment. The subsidiary performance of EMNEs is a significant topic, but has received limited attention. The present study takes a first step towards providing empirical evidence on the extent to which localization strategies by EMNEs affect the link between environmental risks and subsidiary performance when operating in foreign countries. We hope that our 
research will lead to further examination of this issue, which will advance our understanding of EMNEs.

\section{Conclusion}

Adopting resource dependence (Pfeffer \& Salancik, 1978), this paper examines the mediating effect of localization on the relationship between environmental risks and subsidiary performance using a sample of Chinese MNEs. We find that industry risks in host countries reduce the level of input and marketing localization of Chinese MNEs. The reduction in localization negatively affects subsidiary performance. The results show that localization strategies mediate industry risks, but do not mediate the impact of political risk on subsidiary performance. Moreover, there is a direct link between political risks and subsidiary performance. By examining the mediating effect of localization, the study highlights the fact that the impact of industry risks on subsidiary performance depends on the degree of localization, which acts as a mechanism through which industry risks affect EMNEs' subsidiary performance in host countries. Our findings further indicate that SOEs are more vulnerable to industry risks than private firms. Taken together, our study demonstrates that industry risks and political risks affect subsidiary performance in different ways. The impact of industry risks depends on how subsidiaries respond to such risks through adjusting the level of localization, which in turn affects subsidiary performance. However, political risks have a direct impact on subsidiary performance regardless of the level of localization. Evidence was also found that private firms are more capable of dealing with industry risks than SOEs, given different capabilities associated with ownership status. These findings enrich understanding of the links between the various environmental risks and the performance of the subsidiaries of MNEs from emerging economies - an increasingly important group of organizations today. 


\section{Notes}

${ }^{1}$ Established in May 1952, the CCPIT comprises representative individuals, enterprises and organizations in the economic and trade sectors of the country. By the end of 2011, it had nearly 70,000 member enterprises around China.

${ }^{2}$ As basic information in CCPIT's membership enterprises dataset has not been updated, we cannot compare non-responding bias using information such as on the number of employees and sales.

\section{Acknowledgements}

The authors are grateful to Journal of World Business International Editor, Professor David Ahlstrom, and two anonymous reviewers for their constructive comments. This paper was partially funded by research grants from the National Science Foundation of China (\#71172020; \#71472010). 


\section{References}

Acemoglu, D. \& Johnson, S. (2005). Unbundling institutions. Journal of Political Economy, 113: 949-995.

Ahlstrom, D. (2015). From the Editors: Publishing in the Journal of World Business. Journal of World Business, 50: 251-255.

Ahlstrom, D., Bruton, G.D. \& Chan, E.S. 2001. HRM of foreign firms in China: The challenge of managing host country personnel. Business Horizons, 44(3): 59-68.

Ahlstrom, D., Bruton, G.D. \& Lui, S.S.Y. (2000). Navigating China's changing economy: Strategies for private firms. Business Horizons, 43: 5-15.

Ahlstrom, D., Bruton, G. D. \& Yeh, K. S. (2008). Private firms in China: Building legitimacy in an emerging economy. Journal of World Business, 43: 385-399.

Ahlstrom, D., Levitas, E., Hitt, M.A., Dacin, M.T. \& Zhu, H. (2014). The three faces of China: Strategic alliance partner selection in three ethnic Chinese economies. Journal of World Business, 49: 572-585.

Ahuja, G. (2000). The duality of collaboration: Inducements and opportunities in the formation of inter-firm linkages. Strategic Management Journal, 21: 317-343.

Andersen, K. V. (2013). The problem of embeddedness revisited: Collaboration and market types. Research Policy, 42: 139-148.

Andersson, U., Forsgren, M. \& Holm, U. (2002). The strategic impact of external networks: Subsidiary performance and competence development in the multinational corporation. Strategic Management Journal, 23: 979-996.

Beckman, C.M., Haunschild, P.R. \& Phillips, D.J. (2004). Friends or strangers? Firm specific uncertainty, market uncertainty, and network partner selection. Organization Science, 15: $259-275$. 
Birkinshaw, J., Hood, N. \& Young, S. (2005). Subsidiary entrepreneurship, internal and external competitive forces, and subsidiary performance. International Business Review, 14: 227-248.

Brouthers, K. D. \& Hennart, J.-F. (2007). Boundaries of the firm: Insights from international entry mode research. Journal of Management, 33: 395-425.

Bruton, G.D. \& Ahlstrom, D. (2003). An institutional view of China's venture capital industry: Explaining differences of China from the West. Journal of Business Venturing, 18: 233-259.

Bruton, G. D., Ahlstrom, D. \& Yeh, K. S. (2004). Understanding venture capital in East Asia: The impact of institutions on the industry today and tomorrow. Journal of World Business, 39, 72-88.

Bruton, G.D., Peng, M.W., Ahlstrom, D., Stan, C. \& Xu, K. (2015). State-owned enterprises around the world as hybrid organizations. Academy of Management Perspectives, 29: $92-114$.

Buckley, P., Clegg, J., Cross, A., Liu, X., Voss, H. \& Zheng, P. (2007). The determinants of Chinese outward foreign direct investment. Journal of International Business Studies, 38: 499-518.

Casciaro, T. \& Piskorski, M. (2005). Power imbalance, mutual dependence, and constraint absorption: A closer look at resource dependence theory. Administrative Science Quarterly, 50: 167-199.

Chan, C. M., Isobe, T. \& Makino, S. (2008). Which country matters? Institutional development and foreign affiliate performance. Strategic Management Journal, 29: $1179-1205$ 
Chang, E. \& Taylor, M. S. (1999). Control in multinational corporations (MNCs): The case of Korean manufacturing subsidiaries. Journal of Management, 25: 541-565, 41: 882905.

Chang, S.-J., van Witteloostuijn, A. \& Eden, L. (2010). From the editors: Common method variance in international business research. Journal of International Business Studies, 41: $178-184$.

Christensen, C.E. (1997). The innovator's dilemma: When new technologies cause great firms to fail. Boston: Harvard Business School Press.

Cooper, A. C. \& Artz, K. W. (1995). Determinants of satisfaction for entrepreneurs. Journal of Business Venturing, 10: 439-457

Cuervo-Cazurra, A. (2006). Who cares about corruption? Journal of International Business Studies, 37: 803-822.

Cuervo-Cazurra, A. (2008). The effectiveness of laws against bribery abroad. Journal of International Business Studies, 39: 957-979.

Cuervo-Cazurra, A. \& Genc, M. (2008). Transforming disadvantages into advantages: Developing-country MNEs in the least developed countries. Journal of International Business Studies, 39: 957-979.

Cui, L. \& Jiang, F. (2012). State ownership effect on firms' FDI ownership decisions under Institutional Pressure: A study of Chinese outward-investing firms. Journal of International Business Studies, 43: 264-284.

Cui, L., Meyer, K. E. \& Hu, H. W. (2014). What drives firms' intent to seek strategic assets by foreign direct investment? A study of emerging economy firms. Journal of World Business, 49: 488-501. 
Cuypers, I. \& Martin, X. (2010). What makes and what does not make a real option? A study of equity shares in international joint venture. Journal of International Business Studies, 41: 47-69.

Dai, O. \& Liu, X. (2009). Returnee entrepreneurs and firm performance in Chinese hightechnology industries. International Business Review, 18: 373-386.

Das, T. \& Teng, B. (2002). The dynamics of alliance conditions in the alliance development process. Journal of Management Studies, 39: 725-746.

Deephouse, D. L. \& Wiseman, R.M. (2000). Comparing alternative explanations for accounting risk-return relations. Journal of Economic Behavior and Organization, 42: $463-482$.

Delios, A. \& Henisz, W. J. (2003a). Political hazards and the sequence of entry by Japanese firms. Journal of International Business Studies, 34: 227-241.

Delios, A. \& Henisz, W. J. (2003b). Political hazards, experience and sequential entry strategies: The international expansion of Japanese firms, 1980-1998. Strategic Management Journal, 24: 1153-1164.

Deng, P. \& Yang, M. (2015). Cross-border mergers and acquisitions by emerging market firms: A comparative investigation. International Business Review, 24: 157-172.

Doh, J., McGuire, S. \& Ozaki, T. (2015). The Journal of World Business Special Issue: Global governance and international nonmarket strategies: Introduction to the special issue. Journal of World Business, 50: 256-261.

Dunbar, R. L. M. \& Ahlstrom, D. (1995). Seeking the institutional balance of power: Avoiding the power of a balanced view. Academy of Management Review, 20: 171192.

Eden L \& Miller S. (2004). Distance matters: liability of foreignness, institutional distance, and ownership strategy. Advances in International Management, 16: 187-221. 
Elango, B. (2009). Minimizing effects of 'liability of foreignness': Response strategies of foreign firms in the United States. Journal of World Business, 44: 51-62.

Elango, B. \& Pattnaik, C. (2007). Building capabilities for international operations through networks: A study of Indian firms, Journal of International Business Studies, 38: $541-555$.

Fang, Y., Wade, M., Delios, A. \& Beamish, P. W. (2007). International diversification, subsidiary performance, and the mobility of knowledge resources. Strategic Management Journal, 28: 1053-1064.

Feinberg, S. E. \& Gupta, A. K. (2009). MNC subsidiaries and country risk: Internalization as a safeguard against weak external institutions. Academy of Management Journal, 52 : $381-399$.

Figueira-de-Lemos, F., Johanson, J. \& Vahlne, J.E. (2011). Risk management in the internationalization process of the firm: A note on the Uppsala model. Journal of World Business, 46: 143-153.

Fryxell, G., Butler, J. \& Choi, A. (2004). Successful localization programs in China: An important element in strategy implementation. Journal of World Business, 39: 268283.

García-Canal, E. \& Guillén, M. F. (2008). Risk and the strategy of foreign location choice in regulated industries. Strategic Management Journal, 29: 1097-1115.

Garud, R., Jain, S. \& Kumaraswamy, A. 2002. Institutional entrepreneurship in the sponsorship of common technological standards: The case of Sun Microsystems and Java. Academy of Management Journal, 45(1): 196-214.

Gaur, A. S., Delios, A. \& Singh, K. (2007). Institutional environments, staffing strategies and subsidiary performance. Journal of Management, 33: 611-636. 
Gertler, M. S. (2003). Tacit knowledge and the economic geography of context, or the undefinable tacitness of being (there). Journal of Economic Geography, 3: 75-99.

Guillén, M. F. \& García-Canal, E. (2009). The American model of the multinational firm and the "new" multinationals from emerging economies. Academy of Management Perspectives, 23: 23-35.

Gulati, R. \& Sytch, M. (2007). Dependence asymmetry and joint dependence in interorganizational relationships: effects of embeddedness on a manufacturer's performance in procurement relationships. Administrative Science Quarterly, 52: 3269.

Guler, I. \&, Guillén, M. (2010). Institutions and the internationalization of US venture capital firms. Journal of International Business Studies, 41: 185-205.

Habib, M. \& Zurawicki, L. (2002). Corruption and foreign direct investment. Journal of International Business Studies, 33: 291-307.

Haleblian, J., Devers, C.E., McNamara, G., Carpenter, M.A \& Davison, R.B. (2009). Taking stock of what we know about mergers and acquisitions: a review and research agenda. Journal of Management, 35: 469-502.

Hansen, M. T., Mors, M. L. \& Løvas, B. (2005). Knowledge sharing in organizations: Multiple networks, multiple phases. Academy of Management Journal, 48: 776-793.

He, Y., Tian, Z. \& Chen, Y. (2007). Performance implication of nonmarket strategy in China. Asia Pacific Journal of Management, 24: 151-169.

Hennart, J. (2012). Emerging market multinationals and the theory of the multinational enterprise. Global Strategy Journal, 2: 168-187.

Henisz, W. J. (2000). The institutional environment for multinational investment. Journal of Law, Economics and Organization, 16: 334-364. 
Henisz, W. J. (2002). Politics and International Investment. Edward Elgar Publishing: Cheltenham.

Henisz, W. J. \& Delios, A. (2001). Uncertainty, imitation, and plant location: Japanese multinational corporations, 1990-1996. Administrative Science Quarterly, 46: 443475.

Hillman, A., Withers, M., Collins, B. (2009). Resource dependence theory: A review. Journal of Management, 35: 1404-1427.

Hitt, M.A., Ahlstrom, D., Dacin, M.T., Levitas, E. \& Svobodina, L. (2004). The institutional effects on strategic alliance partner selection in transition economies: China vs. Russia. Organization Science, 15: 173-185.

Holburn, G. L. F. \& Zelner, B. A. (2010). Policy risk, political capabilities and international investment strategy: Evidence from the global electric power industry. Strategic Management Journal, 31: 1290-1315.

Hoskisson, R. E., Eden, L., Lau, C. M. \& Wright, M. (2000). Strategy in emerging economics. Academy of Management Journal, 43: 249-267.

Hoyle, R. H. \& Smith, G. T. (1994). Formulating clinical research hypotheses as structural equation models: a conceptual overview. Journal of Consulting and Clinical Psychology, 62: 429-440

Jensen, N. M. (2006). Nation-states and the Multinational Corporation: A Political Economy of Foreign Direct Investment. Princeton, NJ: Princeton University Press.

Jensen, R. \& Szulanski, G. (2004). Stickiness and the adaptation of organizational practices in cross-border knowledge transfers. Journal of International Business Studies, 35 : $508-523$. 
Jimenez, A. \& Delgado-Garcia, J. B. (2012). Proactive management of political risk and corporate performance: The case of Spanish multinational enterprises. International Business Review, 21: 1029-1040.

Johanson, J. \& Vahlne, J-E. (2006). Commitment and opportunity development in the internationalization process: A note on the Uppsala internationalization process model. Management International Review, 46: 1-14.

Kaufmann, D., Kraay, A. \& Mastruzzi, M. (2009). Governance matters VIII: Aggregate and individual indicators, 1996-2008. World Bank Policy Research Paper 4978.

Ketokivi, M. \& Schroeder, R. (2004). Perceptual measures of performance: Fact or fiction? Journal of Operations Management, 22: 247-264.

Kim T-Y., Oh, H., Swaminathan, A. (2006). Framing inter-organizational network change: a network inertia perspective. Academy of Management Review, 31: 704-720.

Kobrin, S. J. (1991). An empirical analysis of the determinants of global integration. Strategic Management Journal, 12: 17-32.

Kostova, T., Roth, K. \& Dacin, M. T. (2008). Institutional theory in the study of multinational corporations: A critique and new directions. Academy of Management Review, 33: 994-1006.

Lacity, M. C. \& Hirschheim, R. (1995). Beyond the Information Systems Bandwagon: The Insourcing Response. New York, NY: Wiley.

Lacity, M. C. \& Willcocks, L. P. (1998). An empirical investigation of information technology sourcing practices: Lessons from experience. MIS Quarterly, 22: 363-408.

Lam, K. S. \& Yeung, J. C. K. (2010). Staff localization and environmental uncertainty on firm performance in China. Asia Pacific Journal of Management, 27: 667-695.

Lambsdorff, J. G. (2003). How corruption affects persistent capital flows. Economics of Governance, 4: 229-243. 
Law, K. S., Song, L. J., Wong, C. \& Chen, D. (2009). The antecedents and consequences of successful localization. Journal of International Business Studies, 40: 1359-1373.

Law, K. S., Wong, C. S. \& Wang, K. (2004). An empirical test of the model on managing the localization of human resource in the People's Republic of China. International Journal of Human Resource Management, 15: 638-648.

Li, S. \& Xia, J. (2008). The roles and performance of state firms and non-state firms in China's economic transition. World Development, 36: 39-54.

Lin, X. (2010). State versus private MNCs from China: Initial conceptualizations. International Marketing Review, 27: 366-380.

Lu, J., Liu, X. \& Wang, H. (2011). Motives for outward FDI of Chinese private firms: Firm resources, industry dynamics and government policies. Management and Organization Review, 7: 223-248

Lu, J., Liu, X., Wright, M. \& Filatotchev, I. (2014). International experience and FDI location choices of Chinese firms: The moderating effects of home country government support and host country institutions, Journal of International Business Studies, 45: $428-449$.

Lu, Y., Zhou, L., Bruton, G. \& Li, W. (2010). Capabilities as a mediator linking resources and the international performance of entrepreneurial firms in an emerging economy. Journal of International Business Studies, 41: 419-436.

Luo, Y. (2003). Market-seeking MNEs in an emerging market: How parent-subsidiary links shape overseas success. Journal of International Business Studies, 34: 290-309.

Luo, Y. \& Peng, M. W. (1999). Learning to compete in a transition economy: Experience, environment and performance. Journal of International Business Studies, 30: 269296. 
Luo, Y. \& Tung, R. L. (2007). International expansion of emerging market enterprises: A springboard perspective. Journal of International Business Studies, 38: 481-498.

Luo, Y., Xue, Z. \& Han, B. (2010). How emerging market governments promote outward FDI: experience from China. Journal of World Business, 45: 68-79.

Luo, Y. \& Zhao, H. (2009). Doing business in a transitional society: Economic environment and relational political strategy for multinationals. Business \& Society, 48: 1-29.

Makino, S., Isobe, T. \& Chan, C. M. (2004). Does country matter? Strategic Management Journal, 25: 1027-1043.

Makino, S., Lau, C.M. \& Yeh, R.S. (2002). Asset-exploitation versus asset-seeking: Implications for location choice of foreign direct investment from newly industrialized economies. Journal of International Business Studies, 403-421.

Meyer, K. Mudambi, R. \& Narula, R. (2011). Multinational enterprises and local contexts: The opportunities and challenges of multiple embeddedness. Journal of Management Studies, 48: 235-252.

Meyer, K. E., Estrin, S., Bhaumik, S. K. \& Peng, M. W. (2009). Institutions, resources, and entry strategies in emerging economies. Strategic Management Journal, 30: 61-80.

Meyer, K.E. and Estrin, S. (2001). Brownfield entry in emerging markets, Journal of International Business Studies, 32: 575-584.

Moran, T. (1985). Multinational Corporations: The Political Economy of Foreign Direct Investment. Lexington, MA: Lexington Books.

Morck, R., Yeung, B. \& Zhao, M. (2008). Perspectives on China's outward foreign direct investment. Journal of International Business Studies, 39: 337-350.

Oh, C. H. \& Oetzel, J. (2011). Multinationals' response to major disasters: How does subsidiary investment vary in response to the type of disaster and the quality of country governance? Strategic Management Journal, 32: 658-681. 
Oliver, C. (1991). Strategic responses to institutional processes. Academy of Management Review, 16: 145-179

Park, S.H. \& Russo, M.V. (1996). When competition eclipses cooperation: an event history analysis of joint venture failure. Management Science, 42: 875-890.

Peng, M. W. (2003). Institutional transitions and strategic choices. Academy of Management Review, 28: 275-296.

Peng, M. W. \& Luo, Y. (2000). Managerial ties and firm performance in a transition economy: The nature of a micro-macro link. Academy of Management Journal, 43: 486-501.

Peng, G. \& Beamish, P. W. (2014). MNC subsidiary size and expatriate control: Resourcedependence and learning perspectives. Journal of World Business, 49: 51-62

Pfeffer, J. (1987). A resource dependence perspective on inter-organizational relations. In Mizruchi, M. S. and Schwartz, M. (Eds.), Intercorporate Relations: The Structural Analysis of bBusiness. Cambridge, UK: Cambridge University Press.

Pfeffer, J. (2003). Introduction to the classic edition. In J. Pfeffer \& G.R. Salancik, The External Control of Organizations: A Resource Dependence Perspective (Vol. 2). New York: Harper \& Row.

Pfeffer, J. \& Salancik, G. (1978). The external control of organizations: A resource dependence perspective. New York: Harper and Row.

Podsakoff, P. \& Organ, D. (1986). Self-reports in organizational research: Problems and prospects. Journal of Management, 12, 531-544.

Porter, M.E. (1990). The competitive advantage of nations. New York: Free Press.

Rangan, S. \& Drummond, A. (2011). The problem of control and the role of home-host ties in explaining multinationals' foreign operations, competitiveness, and performance. Global Strategy Journal, 1: 362-376. 
Ring, P.S., Lenway, S. A. \& Govekar, M. (1990). Management of the political imperative in international business, Strategic Management Journal, 11: 141-151.

Rui, H. \& Yip, G. (2008). Foreign acquisitions by Chinese firms: A strategic intent perspective. Journal of World Business, 43: 213-226.

Schuler, D. A., Rehbein, K. \& Cramer, R. D. (2002). Pursuing strategic advantage through political means: A multivariate approach. Academy of Management Journal, 45: 659672.

Selmer, J. (2004). Expatriates' hesitation and the localization of Western business operations in China. International Journal of International Human Resource Management, 15: $1094-1108$.

Slangen, A. H. \& van Tulder, R. J. (2009). Cultural distance, political risk, or governance quality? Towards a more accurate conceptualization and measurement of external uncertainty in foreign entry mode research. International Business Review, 18: 276291.

Stan, C. V., Peng, M. W. \& Bruton, G. D. (2014). Slack and the performance of state-owned enterprises. Asia Pacific Journal of Management, 31: 473-495.

Tung, R. (2007). The human resource challenge to outward foreign direct investment aspirations from emerging economies: The case of China. International Journal of Human Resource Management, 18: 868-889.

Veliyath, R. \& Ferris, S. P. (1997). Agency influences on risk reduction and operating performance: An empirical investigation among strategic groups. Journal of Business Research, 39: 219-230.

Venaik, S., Midgley, D. \& Devinney, T. (2005). Dual paths to performance: the impact of global pressures on MNC subsidiary conduct and performance, Journal of International Business Studies, 36: 655-675 
Ulrich, D. \& Barney, J. B. (1984). Perspectives in organizations: Resource dependence, efficiency, and population. Academy of Management Review, 9: 471-481.

UNCTD (United Nations Conference on Trade and Development). (2006). World Investment Report - FDI from Developing and Transition Economies: Implications for Development. New York and Geneva.

Waldman, D. A., Ramirez, G. G., House, R. J. \& Puranam, P. (2001). Does leadership matter? CEO leadership attributes and profitability under conditions of perceived environmental uncertainty. Academy of Management Journal, 44: 134-143.

Wang, C., Hong, J., Kafouros, M. \& Wright, M. (2012). Exploring the role of government involvement in outward direct investment from emerging economies. Journal of International Business Studies, 43: 655-676.

Wang, L.C., Ahlstrom, D., Nair, A. \& Hang, R.Z. (2008). Creating globally competitive and innovative products: China's next Olympic challenge. SAM Advanced Management Journal. 73, Summer: 4-14.

Wei, S. J. (2000a). How taxing is corruption on international investors. Review of Economics and Statistics, 82: 1-11.

Wei, S. J. (2000b). Local corruption and global capital flows. Brookings Papers on Economic Activity, 2: 303-354.

Woodcock, C. P., Beamish, P. W. \& Makino, S. (1994). Ownership-based entry mode strategies and international performance. Journal of International Business Studies, 25: $253-273$.

Wright, M., Filatotchev, I., Hoskisson, R. E. \& Peng, M. W. (2005). Strategy research in emerging economies: challenging the conventional wisdom. Journal of Management Studies, 42: 1-33. 
Xia, J. (2010). Resource dependence and cross-border constraint-absorption: A study of market entry strategies. Management International Review, 50: 155-183.

Yildiz, H. E. \& Fey, C. F. (2012). The liability of foreignness reconsidered: New insights from the alternative research context of transforming economies. International Business Review, 21: 269-280.

Yiu, D. W., Lau, C.M. \& Bruton, G. D. (2007). International venturing by emerging economy firms: the effects of firm capabilities, home country networks, and corporate entrepreneurship. Journal of International Business Studies, 38: 19-40.

Young, M.N., Tsai, T., Wang, X., Liu, S. \& Ahlstrom, D. (2014). Strategy in emerging economies and the theory of the firm. Asia Pacific Journal of Management, 31: 331354.

Zhao, Z. J. \& Anand, J. (2009). A multilevel perspective on knowledge transfer: Evidence from the Chinese automotive industry. Strategic Management Journal, 30: 959-983.

Zhou, L., Wu, W. \& Luo, X. (2007). Internationalization and the performance of born-global SMEs: The mediating role of social networks. Journal of International Business Studies, 38: 673-690. 
Table 1: Means, standard deviations and correlations

\begin{tabular}{|l|l|l|l|l|l|l|l|l|l|l|l|l|}
\hline & Mean & S.D. & 1 & 2 & 3 & 4 & 5 & 6 & 7 & 8 & 9 & 10 \\
\hline 1. Subsidiary performance & 3.96 & 0.88 & 1 & & & & & & & & \\
\hline 2. Input localization & 1.97 & 1.14 & $0.44^{* *}$ & 1 & & & & & & & & \\
\hline 3. Marketing localization & 4.26 & 0.98 & $0.59^{* *}$ & $0.36^{* *}$ & 1 & & & & & & & \\
\hline 4. Political risks & 2.06 & 0.81 & $0.19^{*}$ & 0.10 & 0.13 & 1 & & & & & & \\
\hline 5. Industry risks & 1.86 & 0.74 & $-0.34^{* *}$ & $-0.77^{* *}$ & $-0.23^{* *}$ & -0.06 & 1 & & & & & \\
\hline 6. Firm age & 17.34 & 15.04 & 0.05 & -0.03 & 0.01 & 0.04 & 0.07 & 1 & & & & \\
\hline 7. Firm size & 6.59 & 2.26 & 0.09 & 0.01 & 0.01 & -0.13 & 0.05 & $0.35^{* *}$ & 1 & & & \\
\hline 8. Local experience & 3.09 & 2.75 & 0.06 & -0.04 & 0.05 & -0.10 & 0.04 & 0.04 & -0.07 & 1 & & \\
\hline 9. Entry mode & 0.72 & 0.45 & -0.05 & -0.13 & -0.03 & -0.02 & 0.09 & 0.04 & $0.15^{*}$ & 0.08 & 1 & \\
\hline 10. Ownership & 0.27 & 0.44 & -0.06 & 0.03 & -0.11 & 0.03 & 0.00 & $0.31^{* *}$ & $0.27^{* *}$ & -0.05 & 0.11 & 1 \\
\hline
\end{tabular}

Note: sample size $=206 ;{ }^{*} \mathrm{p}<0.05,{ }^{* *} \mathrm{p}<0.01$; two-tailed test. 
Table 2: Measurement scales and properties

\begin{tabular}{|c|c|c|c|c|}
\hline constructs & Measurement items & $\mathrm{CR}$ & Factor loading & $\mathrm{R}^{2}$ value \\
\hline \multicolumn{2}{|c|}{ Subsidiary performance } & \multicolumn{3}{|c|}{0.89} \\
\hline & Subsidiary profit growth & & 0.82 & 0.68 \\
\hline & Subsidiary sales growth & & 0.86 & 0.73 \\
\hline & Subsidiary market share growth & & 0.88 & 0.78 \\
\hline \multicolumn{2}{|c|}{ Input localization } & \multicolumn{3}{|c|}{0.60} \\
\hline & Local raw materials and components & & 0.78 & 0.60 \\
\hline & Local human resource & & 0.52 & 0.27 \\
\hline & Local financial capital $^{\mathrm{a}}$ & & & \\
\hline \multicolumn{2}{|c|}{ Marketing localization } & \multicolumn{3}{|c|}{0.82} \\
\hline & Developed local networks and partnerships & & 0.79 & 0.62 \\
\hline & Adapted to local customers' needs & & 0.87 & 0.76 \\
\hline & Adapted to the local business culture & & 0.67 & 0.45 \\
\hline \multicolumn{2}{|c|}{ Political risks } & \multicolumn{3}{|c|}{0.98} \\
\hline & Voice and accountability & & 0.79 & 0.62 \\
\hline & Political stability & & 0.88 & 0.77 \\
\hline & Government effectiveness & & 0.99 & 0.98 \\
\hline & Regulatory quality & & 0.98 & 0.96 \\
\hline & Rule of law & & 0.99 & 0.98 \\
\hline & Control of corruption & & 0.98 & 0.96 \\
\hline \multicolumn{2}{|c|}{ Industry risks } & \multicolumn{3}{|c|}{0.72} \\
\hline & Level of industrial competition & & 0.60 & 0.36 \\
\hline & Availability of inputs, raw materials and components & & 0.76 & 0.58 \\
\hline & Prices of inputs, raw materials and components & & 0.67 & 0.45 \\
\hline & Availability of human resource ${ }^{\mathrm{a}}$ & & & \\
\hline & Availability of financial capital $^{\text {a }}$ & & & \\
\hline
\end{tabular}

${ }^{\mathrm{a}}$ indicates item that was dropped during the scale purification process. 
Table 3: Discriminant validity

\begin{tabular}{|l|l|l|l|l|l|}
\hline Constructs & $\begin{array}{l}\text { International } \\
\text { performance }\end{array}$ & Input localization & $\begin{array}{l}\text { Marketing } \\
\text { localization }\end{array}$ & Political risks & Industry risks \\
\hline Subsidiary performance & 0.73 & & & & \\
\hline Input localization & 0.13 & 0.44 & & & \\
\hline Marketing localization & 0.28 & 0.08 & 0.61 & & \\
\hline Political risks & 0.01 & 0.01 & 0.02 & 0.89 & \\
\hline Industry risks & 0.08 & 0.39 & 0.04 & 0.01 & \\
\hline
\end{tabular}

Note: Variances extracted are on the diagonal; square correlations are off-diagonal. 
Table 4: Hypothesis test of alternative model

\begin{tabular}{|c|c|c|c|c|c|c|c|}
\hline Model \& structure & $\chi^{2}$ & $\mathrm{df}$ & $\Delta \chi^{2}$ & NNFI & CFI & RMSEA & SRMR \\
\hline M1: direct effect model & 260.21 & 28 & - & 0.13 & 0.32 & 0.204 & 0.161 \\
\hline $\begin{array}{l}\text { M2: M1 + mediation links } \\
\text { partially mediated model }\end{array}$ & 66.46 & 24 & $\Delta \chi^{2}(\mathrm{M} 1, \mathrm{M} 2)=193.75^{* *}$ & 0.81 & 0.88 & 0.094 & 0.079 \\
\hline $\begin{array}{l}\text { M3: M2+ ML->IL } \\
\text { partially mediated model }\end{array}$ & 49.34 & 23 & $\Delta \chi^{2}(\mathrm{M} 2, \mathrm{M} 3)=17.12 * *$ & 0.88 & 0.92 & 0.076 & 0.073 \\
\hline $\begin{array}{l}\text { M4: M3 direct path=0 } \\
\text { full mediated model }\end{array}$ & 54.92 & 25 & $\Delta \chi^{2}(\mathrm{M} 3, \mathrm{M} 4)=5.58$ & 0.87 & 0.91 & 0.077 & 0.075 \\
\hline $\begin{array}{l}\text { M5: M4+PR->IP } \\
\text { partially mediated model }\end{array}$ & 49.91 & 24 & $\Delta \chi^{2}(\mathrm{M} 5, \mathrm{M} 3)=0.57$ & 0.89 & 0.92 & 0.073 & 0.073 \\
\hline $\begin{array}{l}\text { M6: M4+IR->IP } \\
\text { partially mediated model }\end{array}$ & 54.43 & 24 & $\Delta \chi^{2}(\mathrm{M} 6, \mathrm{M} 3)=5.09^{*}$ & 0.87 & 0.91 & 0.080 & 0.075 \\
\hline
\end{tabular}

Note: ${ }^{*} \mathrm{p}<0.05, * * \mathrm{p}<0.01$ 
Table 5: Multiple-group analysis by ownership

\begin{tabular}{|l|l|l|l|l|l|l|l|}
\hline Model \& structure & $\chi^{2}$ & $\mathrm{df}$ & $\Delta \chi^{2}$ & NNFI & CFI & RMSEA $^{\text {Standardized coefficient }}{ }^{\text {a }}$ \\
\hline M3: baseline model & 49 & 24 & - & 0.89 & 0.93 & 0.073 & - \\
\hline $\begin{array}{l}\text { M3: no parameter constraints two- } \\
\text { groups model }\end{array}$ & 67.21 & 46 & - & 0.90 & 0.94 & 0.048 & - \\
\hline M3_1: IR->IL path equal & 71.86 & 47 & $4.65^{*}$ & 0.89 & 0.93 & 0.052 & $\begin{array}{l}\text { SOEs: } \beta=-1.36^{* *} \\
\text { Private firms: } \beta=-1.03^{* *}\end{array}$ \\
\hline M3_2: IR->ML path equal & 68.11 & 47 & 0.90 & 0.91 & 0.94 & 0.048 & - \\
\hline M3_3: PR->IL path equal & 67.21 & 47 & 0.00 & 0.91 & 0.94 & 0.046 & - \\
\hline M3_4: PR->ML path equal & 67.49 & 47 & 0.28 & 0.91 & 0.94 & 0.047 & - \\
\hline M3_5: PR->IP path equal & 67.26 & 47 & 0.05 & 0.91 & 0.94 & 0.047 & - \\
\hline M3_6: IR->IP path equal & 68.03 & 47 & 0.82 & 0.91 & 0.94 & 0.048 & \\
\hline M3_7: ML->IL path equal & 67.31 & 47 & 0.10 & 0.91 & 0.94 & 0.047 & - \\
\hline M3_8: IL->IP path equal & 68.19 & 47 & 0.98 & 0.90 & 0.94 & 0.048 & - \\
\hline M3_9: ML->IP path equal & 68.64 & 47 & 1.43 & 0.90 & 0.94 & 0.048 & - \\
\hline
\end{tabular}

Note: ${ }^{*} \mathrm{p}<0.05, * * \mathrm{p}<0.01$

${ }^{\text {a }}$ When $\Delta \chi^{2}$ is statistically significant, it indicates that the hypothesis that a certain path is equal for SOEs and private firms is rejected. Therefore, the different standardized coefficients of this path for SOEs and private firms are reported here. 
Figure 1: Mediating path for environment risks

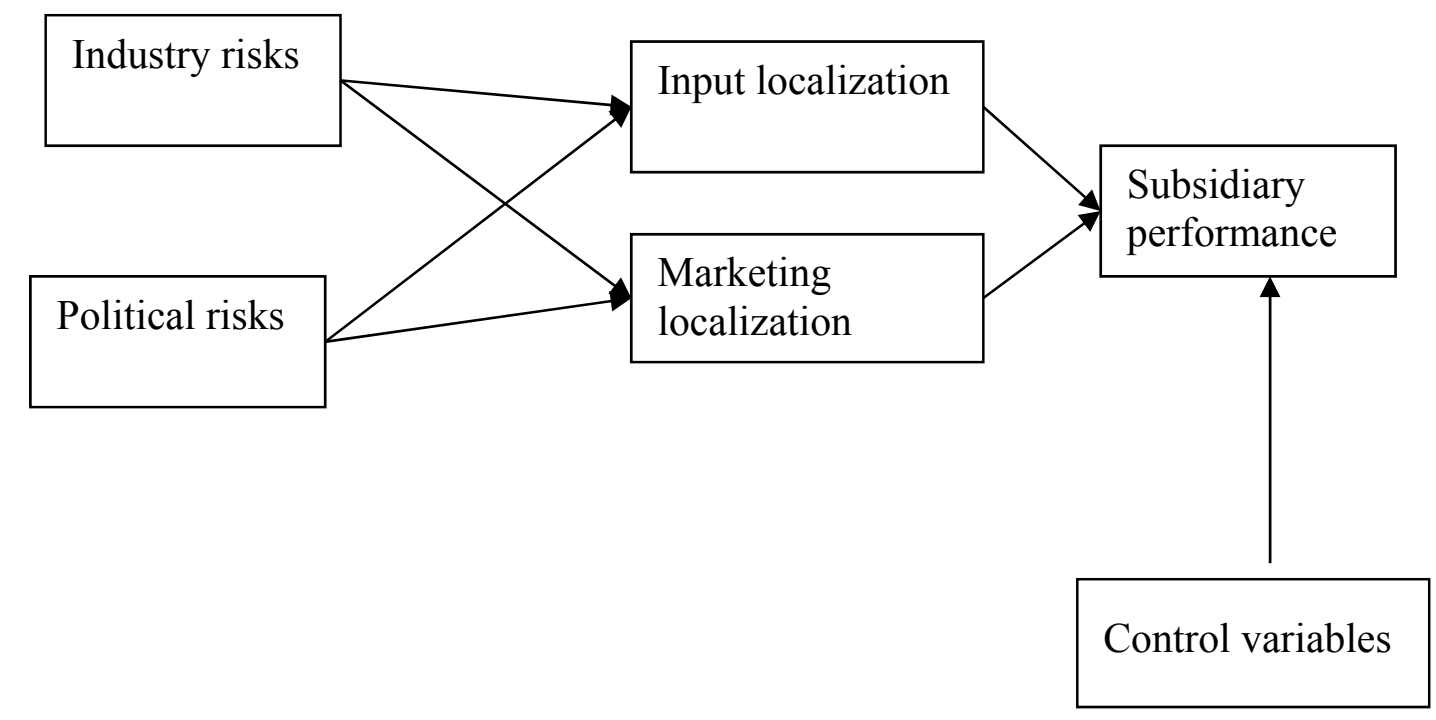


Figure 2: Results of SEM on the partially mediated model M3

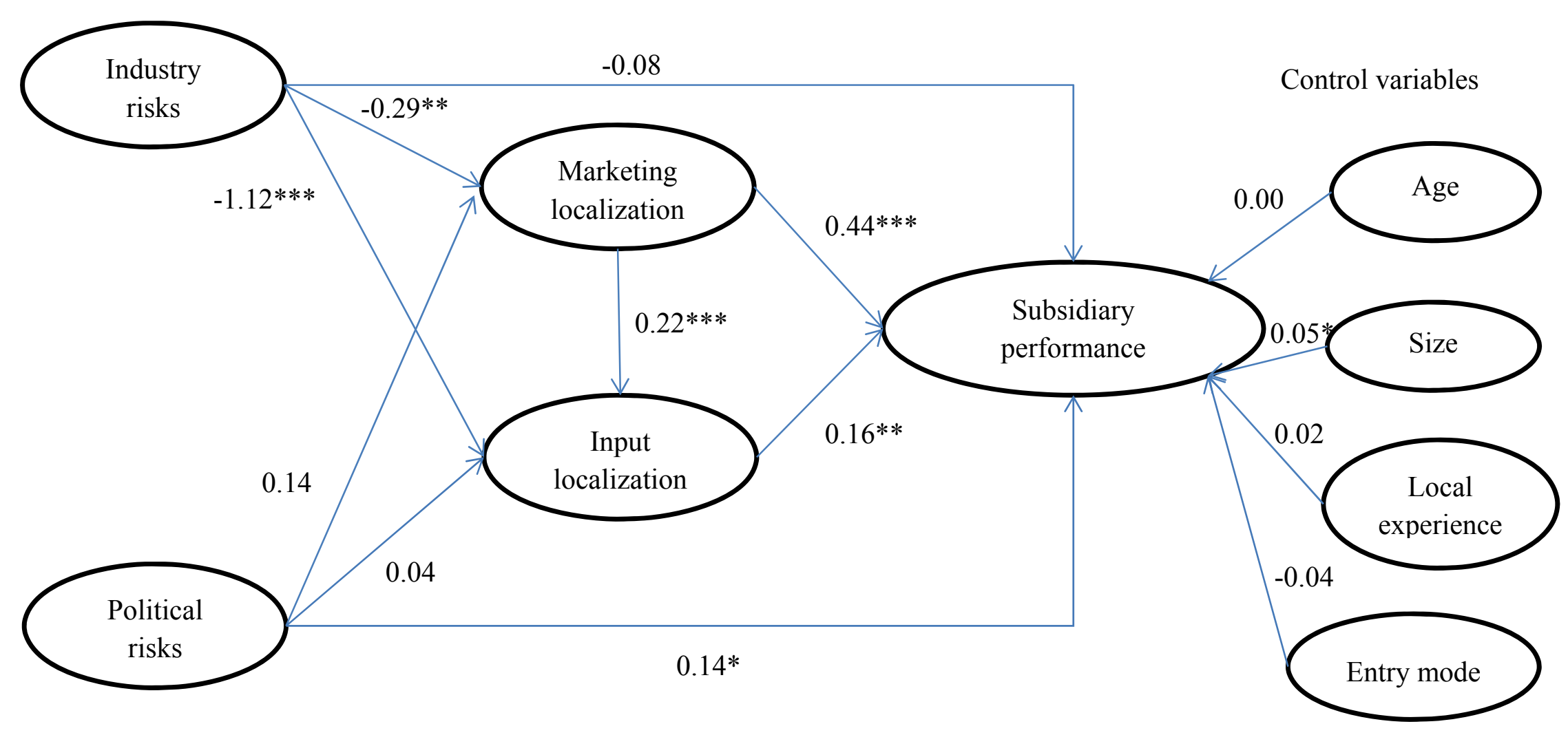

Note: ${ }^{*} \mathrm{p}<0.05,{ }^{* *} \mathrm{p}<0.01,{ }^{* * *} \mathrm{p}<0.001$ 